\title{
Gender Parity in Parliament: A Panacea for the Promotion and Protection of Women's Rights in Nigeria
}

\author{
Bolanle Oluwakemi Eniola* \\ Department of Business and Industrial Law, Faculty of Law, Ekiti State University, Ado-Ekiti, Nigeria
}

Women's rights are part of the fundamental human rights that are recognized in international human rights treaties. While Nigeria has acceded to a number of international instruments on the promotion and protection of women's rights, women in this country have yet to realize their rights. The Nigerian Constitution requires that international treaties be domesticated before they apply in the country. Most of the international instruments on the promotion and protection of women's rights have not been domesticated. One of the reasons is inadequate representation of women in the country's parliament. This is despite the fact that the right of women to participate in decision making processes at all levels is guaranteed in both international and domestic

OPEN ACCESS

Edited by:

Adeoye O. Akinola,

University of Zululand, South Africa

Reviewed by:

Magdalena Zadkowska University of Gdansk, Poland Omololu Michael Fagbadebo, University of KwaZulu-Natal,

South Africa

*Correspondence: Bolanle Oluwakemi Eniola bolanleeniola@ymail.com

Specialty section:

This article was submitted to Gender, Sex and Sexuality Studies,

a section of the journal

Frontiers in Sociology

Received: 31 May 2018 Accepted: 26 October 2018 Published: 06 December 2018

Citation:

Eniola BO (2018) Gender Parity in

Parliament: A Panacea for the Promotion and Protection of Women's Rights in Nigeria. Front. Sociol. 3:34.

doi: 10.3389/fsoc.2018.00034 instruments. This paper examines why Nigerian women are not adequately represented in parliament and the implications for the promotion and protection of their rights. It concludes that gender parity in the legislative houses is essential to agitate for and promote women's rights in this country.

Keywords: gender parity, women's right, political representation, Nigeria, parliament

\section{INTRODUCTION}

Women represent about half of Nigeria's population, but occupy less than 10 percent of political positions (Makama, 2013, p. 116). This affects their capacity to influence the domestication of instruments that protect their rights. The main reason is patriarchy that prevails in most Nigerian communities despite the country having acceded to international human rights treaties that promote gender equality. Gender inequality permeates every level of Nigerian society, including the political sphere.

This gender stratified society assigns rights and responsibilities on the basis of physiological differences between men and women. Men are believed to be physically stronger than women and are expected to be involved in physical activities and more labor oriented tasks. Furthermore, women are seen to be emotionally driven while men are more goal-oriented (Olorunbunmi, 2015, p. 395). Consequently, women are considered to be fit for domestic and reproductive roles while men are regarded as traditional heads of households and wield enormous decision making powers (Gbadamosi, 2007, p. 351).

Women's lack of participation in legislative processes has negatively impacted promotion and enforcement of their rights. An example is the Gender and Equal Opportunity Bill which was presented at the Nigerian Senate for a second reading on 15th March, 2016 and was rejected. One could argue that one of the reasons why the Bill was not passed is because only seven of the 109 
senators are women. Men's efforts, if any, to promote these rights are not sufficient, because they are not direct beneficiaries.

It is against this background that this paper examines the history of women's participation in politics in Nigeria, the legal framework for the promotion and protection of women's rights in the country, the implications of gender parity for the domestication of international treaties protecting women's rights and what could be done to achieve gender equality in the Nigerian Parliament.

\section{THE HISTORY OF WOMEN'S PARTICIPATION IN POLITICS IN NIGERIA}

Nigeria's political history can be divided into three phases: the pre-colonial, colonial, and postcolonial eras. While, as noted previously, Nigerian culture is strongly patriarchal, this does not mean that women were absent from politics during the pre-colonial era. Indeed, they contributed immensely to the development of Nigerian society prior to colonialism. This changed when the country fell under British rule and this state of affairs persists in the post-colonial era.

\section{Women's Political Participation in Pre-colonial Nigeria}

During the pre-colonial period, Nigeria's political structure was purely monarchical. The country was made up of diverse societies and kingdoms. Women participated actively in both the private and public spheres, and influenced the socio-political landscape of the various regions. They actively contributed to the political development of their societies as rulers in some communities, and served as queens, as regents on the death of the substantive king, and were crowned chiefs. Women also served as advisers to the kings to ensure the growth and survival of the community and helped to dispense justice at the palace courts.

In the southern part of Nigeria, women played significant roles in the palace administration and the roles of the king's wives, and queen mothers were noteworthy. In the southeast, women's interests were well represented at the palace as there were female monarchs known as Omu whose efforts complemented that of the male monarch (Obi) (Nelson, 2012, p. 89).

Similarly, prior to the advent of Islam and colonialism in northern Nigeria, women played prominent roles in political affairs (Anyogu and Arinze, 2013, p. 3). For example, in the administration of Kanem-Bornu, the queen mother who was known by the title Magira assisted the king in decision making. In the same vein, the king's first wife, called Gumsu and his official elder sister, known as Megara exercised much influence in decision making (Adjepong, 2015, p. 29) Furthermore, women in pre-colonial Nigeria took up arms and joined their male counterparts to defend the independence and sovereignty of their kingdoms or for the purposes of territorial expansion. An example is Queen Amina of Zaria, who was a soldier and empire builder. She became the ruler of her city in 1576 (Abdul et al., 2011). It is also on record that the Igala Kingdom-also in the northern part of the country-was founded by a woman (Abdul et al., 2011).
In southwestern Nigeria, some women participated alongside men in different wars, notably the Kiriji war. This enabled them to take on greater political responsibilities. Examples include the Iyalode of Egba and the Iyalode of Ibadan (Abdul et al., 2011). The position of Iyalode is one of great privilege and power. Ife traditions also recall an early warrior queen, moremi (Falola, 2007).

It is clear that women contributed to the development of precolonial society by way of their good counsel and by helping enact laws regulating the activities of members of various societies through their participation in the palace courts. One could argue that their contributions equaled those of the prominent males in society as they acted as rulers of their communities in some instances and functioned well in that capacity. Some were even warriors. Thus, during the precolonial era, women were not regarded as subordinate to men, but rather as contemporaries as they held complementary positions with men within their communities (Olomojobi, 2013, p. 217). While their rights were limited by a number of constraints such as social bottle-necks, child bearing and rearing, and domestic work and although it cannot be claimed that there was gender parity in political participation during this era, women played vital roles in their communities.

\section{Women's Political Participation in Colonial Nigeria}

The lives of Nigerian women under colonialism were characterized by political inactivity. The colonial administration ushered in "European patriarchy." Europeans considered women as subordinate to men and held stereotyped perceptions of women's roles in the domestic and public domains (IgbelinaIgbokwe, 2013, p. 632). Women were not allowed to participate in politics and were only able to do so following protest action (Kent, 1990, p. 28-30).

According to Okome, "These elements of institutionalized male dominance were in no small measure due to Victorians' ideology, in which women were generally restricted from full participation in the public sphere" (Okome, 2002, p. 33). Women were restricted to the home front and were marginalized and undermined while men held positions of power (Okome, 2002, p. 33).

The colonial administration impacted on Nigerian women in different ways, most of which were detrimental to their well-being (Anyogu and Arinze, 2013, p. 5). The colonialists' economic system was export-oriented and gave men more opportunities to participate than women. Women were denied access to mediumand long-term loans, which were required for bulk purchases. Little recognition was given to women's traditional economic and socio-political status, placing them at a severe economic disadvantage (Okome, 2002, p. 33).

The communal roles that were handled by women gradually withered away (Olomojobi, 2013, p. 217) and they were unable to participate in the administration of their societies. For example, the legal system restricted women's role in dispensing justice (Okome, 2002, p. 33). They did not have a say on the various policies that affected them, further entrenching female 
subordination. “... [The] Western education system introduced with the advance of colonialism overwhelmingly benefited males to the disadvantage of women. Only few females gained access to Western education" (Adjepong, 2015, p. 37) and men had more job opportunities. Furthermore, women became marginalized in indigenous political institutions.

However, women were not completely docile during this period. They formed women's organizations that acted as pressure groups to express their disapproval of imperialist policies which were not favorable to women and to articulate their demands. A good example is the 1929 Aba women's riot where women protested against outrageous increases in tax, forced labor and political marginalization (Allen, 1975, p. 22).

\section{Women's Political Participation in Post-colonial Nigeria}

Gender imbalances during the colonial era carried over into the post-colonial era. While the Constitutional Order in Council which heralded Nigeria's independence included fundamental human rights (Chapter 3 of the 1960 Constitution) and section 27 of the Constitution guaranteed freedom from discrimination, women remained marginalized. Independence “... was only a change in the composition of office holders and not in the character of the political system" (Nelson, 2012, p. 91).

This was evident in the composition of parliament in the first republic (1960-1966), with only two women elected to the federal parliament out of 91 senators and two also elected to the Eastern House of Assembly. Civilian rule was truncated by military rule from 1966 to 1979, during which time women were further marginalized (Oloyede, 2016).

In the second republic (1979-1983), there was only one female senator out of 571 and 11 females in the 445-member House of Assembly. In the 19 states of the federation, there were no female representatives in the House of Assembly or at local government level (Omotola, 2007, p. 37). The second republic was truncated by a military dictatorship in 1983. During this period, the federal government introduced the first formal quota system which mandated the Executive Council of all states to ensure that at least one of its members was a woman. All states complied with this directive and some had more than one female member. In the early 1990s, two women were appointed deputy Governors, namely, Alhaja Latifat Okunu of Lagos State and Mrs. Pamela Sadauki of Kaduna State (Oloyede, 2016).

However, there were no female members in the Supreme Military Council or the later Armed Forces Ruling Council, meaning that women played no significant role in the central government (Oloyede, 2016).

Women's participation was equally low during the third republic. Few women were elected as councilors, only one woman served as a local government chairperson, there were no female governors, only one woman won a seat in the senatorial election in 1982 (Mrs. Kofo Bucknor Akerele) and very few women were elected to the House of Representatives (Oloyede, 2016).

Nigeria returned to democratic rule in 1999 and the Constitution of the Federal Republic of Nigeria (1999, as amended) gives men and women equal rights and opportunities in terms of participation in politics. Section 14(1) states that, "The Federal Republic of Nigeria shall be a state based on the principles of democracy and social justice." Subsection 2 goes further to state that, "The participation by the people in their government shall be ensured in accordance with the provisions of this Constitution."

Equally, section 40 of the Constitution states that, "Every person shall be entitled to assemble freely and associate with other persons, and in particular he may form or belong to any political party, trade union or any other association for the protection of his interest." section 42 (1) provides that, " A citizen of Nigeria of a particular community, ethnic group, place of origin, sex, religion or political opinion shall not, by reason only that he is such a person be subjected to any form of discrimination."

Apart from the constitutional provisions that promote women's political participation, as noted earlier, Nigeria is a signatory to a number of international instruments that address gender inequality. Article 7 of the Convention on the Elimination of all Forms of Discrimination Against Women (CEDAW) states that:

State parties shall take all appropriate measures to eliminate discrimination against women in the political and public life of the country and, in particular, shall ensure to women on equal terms with men the right:

(a) To vote in all elections and public referenda and to be eligible for election to all publicly elected bodies;

(b) To participate in the formulation of government policy and the implementation thereof and to hold public office and perform all public functions at all levels of government;

(c) To participate in non-governmental organizations and associations concerned with the public and political life of the country.

At regional level, women's political participation and representation is provided for in Article 9(1) of the Protocol to the African Charter on Human and People's Rights on the rights of Women in Africa:

State Parties shall take specific positive action to promote participative governance and the equal participation of women in the political life of their countries through affirmative action, enabling national legislation and other measures to ensure that women participate without any discrimination in all elections.

Apart from the international and regional treaties that promote women's political representation, some international conventions support gender parity in political participation. The Beijing Declaration and Platform for Action addressed various aspects of women's lives in relation to the realization of their human rights. It stated that States should take "measures to ensure women's equal access to and full participation in power structures and decision making" (Strategic objective G.1) and "must increase women's capacity to participate in decision making and leadership" (Strategic objective G.2). Nigeria also has some policy frameworks in place to ensure gender parity in political participation. However, gender imbalances in the political sphere 
persist and parliament has been dominated by men since the return to democracy in 1999.

In 1999, only three of the 109 members of the Senate were female. This increased to eight in 2007, but in 2011 only seven female members were elected, and eight in 2015. Female representation in the House of Representatives is equally low; in 1999 , there were only 12 female members out of 360 , with 21 in 2003, 26 in 2011 and 19 in 2015 (Uzoanya and Awodipe, 2015). Female representation has also been low in the Houses of Assembly in all states, although some progress has been made over the years. In 1999 only 12 women were elected in the whole federation, rising to 38 in 2003, 52 in 2007 and 62 in 2011 (Oloyede, 2016).

The following section explores the various factors that impede women's participation in politics in Nigeria.

\section{FACTORS INHIBITING WOMEN'S PARTICIPATION IN POLITICS IN NIGERIA}

Among the factors inhibiting women's participation in politics in Nigeria are:

(a) Gender: The predominantly patriarchal nature of Nigerian society that dictates behavior along gendered lines, coupled with the country's political experience during the colonial era has had a devastating effect on women's political participation.

"Gender has over the years, portrayed women as weaker sex. The concept of gender represents the woman as one who is superficial with interest mainly in fashion, beauty and little love for deep thinking" (Awajiusuk, 2015, p. 99). In line with this thinking, female children are socialized to regard themselves as subordinate and their primary duty is taking care of the home and child bearing and rearing when they reach adulthood. In contrast, male children are trained to play leadership roles from infancy (Awajiusuk, 2015, p. 104). Thus, women that participate in politics contravene culturally assigned gender roles.

This results in an unequal balance of power as women are marginalized and excluded from politics due to the belief that they are subordinate and are not fit for public engagement (Nwabunkeonye, 2014: 287). Indeed, some Nigerian cultures forbid women from occupying leadership positions as they believe that they cannot lead men.

(b) Biological roles: The demands imposed by women's biological roles of child bearing and rearing might also inhibit their participation in politics. Moreover, when they do venture into politics, they are likely to avoid elective positions that are time consuming and prefer to provide logistical support.

(c) Dual Nativity: The Nigerian Constitution grants women dual nativity. This means that they have equal rights in both their place of birth and those of their husbands. Although some are of the opinion that this gives women an edge in politics, in reality, it is a hindrance because women do not know where they truly belong. In her place of birth, her kinsmen might not vote for her due to the cultural belief that she ceases to be part of them as soon as her bride price is paid. Equally, her husband's kinsmen might not recognize her as one of them.

(d) The Demands of Politics: Politics is time consuming and involves traveling and meetings that could last late into the night. This discourages women from entering politics as responsible wives are expected to be home taking care of their family. Moreover, Nigerian politics is marred by political violence and intimidation of both voters and candidates during elections, further hindering women's participation.

(e) Stigmatization of women in politics: Given the political environment in Nigeria, many believe that politicians have no regard for human rights. The fact that politics is male dominated leads to misconceptions that the few women in their midst can only make headway if they compromise their virtue. Hence, they are regarded as being of easy virtue and culturally rebellious, among other things (Nwabunkeonye, 2014, p. 287).

(f) Finance: Competing for political positions in Nigeria requires huge financial back up that most women cannot access. Financial requirements include registration and nomination fees which are exorbitant, and paying for election campaigns, among others. As noted previously, economic marginalization of women is one of the colonial legacies. Women in Nigeria have yet to measure up to their male counterparts financially. Their economic disempowerment stems from the sexual division of labor, denial of property rights, and job opportunities offered on the basis of sex, among others. This gives men an edge over women (Agbalajobi, 2010, p. 78). In the same vein, voters regard elections as an opportunity to obtain money from candidates as they are not sure they will keep their promises if elected. They hence vote for the highest bidder (Ekpenyong et al., 2015, p. 9). Monetisation of political office has thus negatively impacted women's participation in politics.

(g) Cultural and religious inhibitions: Most cultures in Nigeria do not afford women political rights. A woman's rights are believed to be subsumed in her husband. Payment of a bride price, which is widespread in Nigeria, gives a man control over his wife. A husband could prevent his wife from participating in politics or taking up a political appointment if she does not seek his approval (Obi, 2008, p. 73). The two major religions in the country (Christianity and Islam) preach that women should be submissive and by implication are not expected to be leaders, further enhancing their political marginalization.

\section{THE LEGAL FRAMEWORK FOR THE PROTECTION OF WOMEN'S RIGHTS IN NIGERIA}

\section{International and Regional Instruments}

As a member of the international community, Nigeria has signed and ratified a number of international and regional human rights instruments that promote women's rights (the Universal 
Declaration of Human Rights, 1948; International Covenant on Economic, Social and Cultural Rights, 1966; International Covenant on Civil and Political Rights, 1966; CEDAW, 1979; African Charter on Human and People's Rights, 1981; Protocol to the African Charter on Human and People's Rights, 2003; and the Solemn Declaration on Gender Equality in Africa, 2004, among others). These instruments are all encompassing as they protect women's economic, social, cultural, civil, and political rights, among others.

However, as noted previously, the Nigerian Constitution requires that an international treaty must be domesticated in order for it to apply (section 12 of the 1999 Constitution). Most of the international and regional human rights instruments specifically enacted for the promotion of women's rights have yet to be domesticated (CEDAW and the Protocol to the African Charter on Human and People's Rights on the Rights of Women in Africa).

\section{The Constitution}

In addition to the international instruments ratified by Nigeria, domestic instruments include extant provisions on the protection of human rights. These include certain provisions of the 1999 Constitution. Chapter II deals with the Fundamental Objectives and Directive Principles of State Policy. According to section $17(1)$, the state's social order is founded on the ideals of freedom, equality and justice. Section 17(2) notes that in furtherance of the social order: (a) every citizen shall have equality of rights, obligations and opportunities before the law; and (b) the sanctity of the human person shall be recognized and human dignity shall be maintained and enhanced. The implication of section 17 is that there should be no disparity of any kind; all citizens, whether male or female, should be treated equally. This suggests that male citizens should not dominate their female counterparts. However, the provisions of Chapter II of the Constitution are mere policy guidelines and are not justiciable [section 6(6) (c) of the 1999 Constitution]. Accordingly, they do not grant legal rights to Nigerian citizens, and their breach cannot be redressed in court. Chapter IV of the Constitution recognizes various human rights, particularly in relation to civil and political rights. These include the right to life, dignity, personal liberty, private and family life, freedom from discrimination, freedom of thought, conscience and religion, and the right to freedom of expression and the press. Apart from section 42 which prohibits discrimination on the grounds of sex, the Constitution contains no specific and substantive provisions on the protection of women's rights.

It is thus evident that although the Nigerian Constitution has the intention to protect women's rights, it does not take into consideration that, women are vulnerable and that the fact that Nigerian society is a patriarchal one invariably affects the realization of such rights.

\section{National and State Legislation on the Promotion of Women's Rights in Nigeria}

Nigeria is a democratic state and operates a federal system of government. The Constitution assigns legislative powers to the federal and state legislatures according to two lists (exclusive and concurrent). Matters that fall under the exclusive legislative list are reserved for the National Assembly, while the concurrent legislative list contains matters that both the national and state legislatures could legislate on. Issues touching on women's rights fall under the concurrent legislative list. It follows that both the federal and state governments have the capacity to legislate on women's rights. National government and some state governments have enacted laws that protect women's rights.

\section{National Legislation on the Protection of Women's Rights in Nigeria}

Apart from the Constitution, other national legislation contains provisions that protect women's rights in Nigeria. These include the Criminal Code and Penal Code, the Marriage Act, the Violence against Women Prohibition Act, and Trafficking in Persons (Prohibition) Law Enforcement and Administration Act, 2003, among others.

\section{State Legislation on the Protection of Women's Rights in Nigeria}

As noted previously, the Constitution empowers states to legislate on issues that are not on the exclusive legislative list (section 4 of the 1999 Constitution) through their various Houses of Assembly. States have made concerted efforts to further advance women's rights. Some have criminalized female genital mutilation and prescribed penalties for violators of the law (the Edo State Female Circumcision and Genital Mutilation Prohibition Law (1999); Cross River State Girl Child Marriages and Female Circumcision (Prohibition Law) (2000); Rivers State Abolition of Female Circumcision Law (2001); Ogun State Female Circumcision and Genital Mutilation (Prohibition) Law (2000); and Ekiti State Gender-Based Violence (Prohibition) Law (2001), among others )while others have adopted laws to protect the fundamental rights of widows (Enugu State Protection of Widows and Widowers Fundamental Rights Law (2001); Oyo State Widow's Empowerment Law (2002); and Anambra State Malpractices against Widows and Widowers Prohibition Laws (2004), among others). Some states also have laws in place to curb the negative impacts of cultural practices on the realization of women's rights (the Prohibition of Early Marriage Law, Kebbi State; Retention in School and against withdrawal of Girls from School Law, Kano State; and Violence against Women Law, Lagos State, among others). Indeed, Imo, Anambra, Ekiti, Plateau and Kogi states are ahead of the Federal Government in enacting Gender and Equal Opportunities Law. One of the objectives is to provide equal opportunities for all irrespective of gender and prohibit gender based discrimination. In states where these laws have been enacted, men and women have equal rights in all spheres including the political one.

Despite these robust legal frameworks, Nigerian women still suffer many kinds of discrimination in both the private and public spheres. One of the reasons is that the domestic instruments are inadequate and in most cases their provisions are not in consonance with those of international human rights instruments. An example is the Marriage Act which does not set a minimum age for marriage, although it punishes marriage with a minor without obtaining the required consent (section 48 of the Marriage Act, CAP M6 LFN, 2004). Equally, section 55 of 
the Penal Code allows a husband to beat his wife for the purpose of correcting her. Furthermore, the Nigerian criminal code does not recognize marital rape. All these examples run contrary to the provisions of CEDAW and the Protocol to the African Charter on the Rights of Women in Africa, to which Nigeria is a signatory.

Finally, there are geographical disparities in the enjoyment of women's right in Nigeria. Women in states where a law has been enacted to protect a particular right will enjoy such rights, while those in a neighboring state might not have access to similar benefits.

It is implicit from the foregoing that the various international instruments on women's rights which Nigeria has ratified should be domesticated. One of the reasons why this has not been achieved is gender imbalances in the legislative houses in Nigeria. The following section explores what Nigerian women stand to gain if there were to be gender parity in parliament.

\section{THE IMPLICATIONS OF GENDER PARITY IN PARLIAMENT FOR THE DOMESTICATION OF INTERNATIONAL TREATIES PROTECTING WOMEN'S RIGHTS IN NIGERIA}

Sustainable Development Goal No. 5 states that, gender equality is a human right. This implies that women should enjoy the same status as men so that they can fully realize their human rights and have a meaningful impact in their respective societies.

As noted previously, the Nigerian parliament is male dominated despite the fact that the country's Constitution guarantees the right of every citizen to participate in politics. Equally, the Constitution recognizes women's right to vote for and be voted in as members of parliament (sections 77 and 106 of the 1999 Constitution).

In addition to these constitutional provisions, Nigeria's National Gender Policy aimed to increase the number of women in political office, party organs, and public life by setting a goal of 35 percent affirmative action in favor of women in all elected and appointed positions by 2015 . However, it is clear that women in Nigeria have yet to benefit from these provisions as few hold political office. Such male domination has significantly impeded the protection and promotion of women's rights. For example, the Senate recently threw out a Gender and Equal Opportunities Bill which could have afforded Nigeria the opportunity to domesticate some of the provisions of the CEDAW, and the Protocol to the African Charter on Human and People's Rights on the Rights of Women in Africa. The Bill was opposed by male senators (Goitom, 2016) and women could do nothing as the Nigerian parliament uses a voice voting system. It might have been passed had there been gender parity in the Senate.

Gender imbalances at the political level are not unique to Nigeria; some African countries with a similar political background have also yet to achieve gender parity in political representation.

Kenya has a similar political history and cultural background to Nigeria. Notwithstanding Kenyan women's involvement in mobilization for independence, they did not have equal political access after independence (Nzomo, 1997: 233). However, the women's movement adopted a women's agenda for 30-35 percent female representation in parliament and political appointments (Nzomo, 1997: 244-245). This resulted in their improved participation in politics. Although, gender parity has yet to be achieved, the increased number of women in politics has brought about fundamental change in the promotion of women's rights in Kenya (Nzomo, 1997, p. 245).

Ghana is another African country with a similar political and historical background. Women in Ghana were active and contributed immensely to the development of the country during the precolonial and colonial eras (Adjepong, 2015, p. 26). Nonetheless, there is a paucity of women in parliament despite the fact that the Constitution recognizes equal political rights and that the country is a signatory to a number of international instruments that promote women's political rights. Women occupied only 16 of 200 parliamentary seats in 1995 and 25 seats out of 230 in the 2004 national election (Sossou, 2011, p. 1).

This is in contrast to African countries like South Africa, Tanzania and Rwanda where a large number of women have been elected to parliament. In South Africa, women make up around 40 percent of members of parliament, compared to Nigeria, where their representation is as low as 7 percent (beta. Data. World bank.org).

In the Republic of Tanzania, the number of women legislators is increasing steadily, while in Rwanda, women occupy about 56 percent of the seats in parliament and in Burundi, 42 percent of the deputies in the National Assembly are female.

South Africa's legal framework for the protection of women's rights is exceptional as the various international instruments which cover all forms of discrimination against women have been domesticated. One could argue that one of the reasons for this state of affairs is that, unlike Nigeria, women are well represented in this country's parliament.

Were gender parity to be achieved in Nigeria's parliament, women would be able to lobby for the domestication of treaties on women's rights. This is evident in women's activities in the current National Assembly in promoting Bills that protect women's rights. Bills initiated/sponsored by women in the Senate include the Gender and Equal Opportunities Bill (Senator Abiodun Olujimi); Equal Opportunity Commission Bill (Senator Abiodun Olujimi); Sexual Harassment in Tertiary Institutions Prohibition Bill(Senator Omo Ovie Agege; cosponsored by 45 senators including the seven female senators in the 8th National Assembly); and the Marketing (Breast-Milk) Substitutes Act Amendment Bill (Senator Betty Apiafi), among others (PLAC., 2017).

\section{CONCLUSION}

This paper has shown that while women in Nigeria were active and competent and made considerable contributions to the development of society during the pre-colonial era, colonial policies marginalized them and their contributions 
to society were reduced to the barest minimum. Colonialism further entrenched the patriarchal bias of Nigerian society, with devastating consequences for women's participation in politics.

Despite the fact that Nigeria is now an independent, democratic country with an admirable legal framework that embraces gender equality at all levels of society, women are under-represented in the political sphere. This paper highlighted some of the reasons for this state of affairs.

It is thus recommended that government and nongovernmental organizations collaborate and implement far reaching programmes on women's rights that will bring about the desired changes through public awareness, enlightenment and education.

Furthermore, an amendment to the Constitution is required to define the state of origin of a married woman for the purpose of political representation. An additional amendment should be adopted to provide for gender parity in political representation. Kenya's Constitution states that no more than two-thirds of the members of elected or appointed bodies shall be of the same gender (Article 27(8) of the Constitution of Kenya, 2010).

\section{REFERENCES}

Abdul, M. M., Adeleke, O., Adeyeye, O., Babalola, A., Eyo, E., Ibrahim, M. T., et al. (2011). Analysis of the History, Organisation, and Challenges of Feminism in Nigeria. Available online at: www.nawey.net/wp-content/uploads/downloads/ 2012/05/Feminism-in-Nigeria.pdf

Adjepong, A. (2015). "The role of African women in the political development of pre-colonial Africa: a historical analysis," in Women in Development Essays in Memory of Prof. D.O Akintunde, eds S. A. Ajayi and J. K. Ayantayo (Ibadan: John Archers Publishers Ltd.), 17-39.

Agbalajobi, D. T. (2010). Women's participation and the political process in Nigeria: problems and prospects. Af. J. Polit. Sci. Relat. 4, 75-82.

Allen, J. V. (1975). Aba riots or the Igbo women's war?-Ideology, stratification and the invisibility of women. Ufahamu J. Af. Stud. 6, 59-85.

Anyogu, F., and Arinze, C. (2013). Gender inequality and colonization: Nigeria in legal perspective. J. Const. Law 1, 1-13. Available online at: http://www. academia.edu/6005537/gender_inequality_and_colonization_Nigeria_in_ legal_perspective_journal_of_constitutional_law_vol.1_no._1_2013

Awajiusuk, F. J. (2015). "Gender imbalance in Nigerian politics: a religio-cultural approach," in Women in Development Essays in Honour of Prof. D.O Akintunde, eds S. A. Ajayi and J. K. Ayantayo (Ibadan: John Archers Publishers Ltd.), 95-108.

Ekpenyong, O., Ibiam, O. K., and Agha, E. O. (2015). Politics in Nigeria: to what extent has gender agenda gained momentum. IOSR J. Hum. Soc. Sci. 20, 1-10.

Falola, T. O. (2007). The Role of Nigerian Women. Available online at: http://www. britainnica.com

Gbadamosi, O. (2007). Reproductive Health and Rights (African Perspectives and Legal Issues in Nigeria). Benin: Ethiope Publishing Corporation.

Goitom, H. (2016). Equal Protection, Human Rights and Civil Liberties, Women's Rights. Available online at: www.loc.gov

Igbelina-Igbokwe, N. (2013). Contextualizing Gender Based Violence Within Patriarchy in Nigeria. Available online at: http://pambazuka.org/en/category/ features/87597

Kent, S. K. (1990). Sex and Suffrage in Britain, 1860-1914. Princeton: Princeton University Press.

Makama, G. A. (2013). Patriarchy and gender inequality in Nigeria: the way forward. Eur. Sci. J. 9, 115-144. doi: 10.19044/esj.2013.v9n17p\%25p

Nelson, E. E. (2012). Democracy and the struggle for political empowerment of women in Nigeria. Int. J. Adv. Stud. Govern. 3, 85-99.
Equally, the Constitution of Rwanda provides that women should make up 30 percent of decision making bodies (Article 9(4) of the Constitution of the Republic of Rwanda, 2003). In line with the National Gender Policy, the Nigerian Constitution should be amended to state that women should occupy 35 percent of elected and appointed positions.

Finally, women themselves are the most critical instrument in ensuring that their voices are heard in politics. Like women in pre-colonial Nigeria, they need to rise to the occasion and take advantage of the opportunities that society offers them. A gender balance in parliament would enable women to lobby for the domestication of the various international instruments on women's rights which Nigeria has ratified, thus enhancing the promotion and protection of women's rights in this country.

\section{AUTHOR CONTRIBUTIONS}

The author confirms being the sole contributor of this work and has approved it for publication.

Nwabunkeonye, U. P. (2014). Challenges to women active participation in politics in Nigeria. Sociol. Anthropol. 2, 284-290. doi: 10.13189/sa.2014.020704

Nzomo, M. (1997). "Kenya women in politics and public decision making," in African Feminism: The Politics of Survival in Sub-Saharan Africa, ed G. Mikel (Philadelphia: University of Pennsylvania), 232-254.

Obi, M. A. (2008). "A theoretical analysis of the socio-economic and political implications of bride price on the Nigerian woman," in Bride Price and the Implications for Women's Rights in Nigeria, eds J. N. Ezeilo and J. E. Alumanah (Enugu: Women Aid Collective), 63-76.

Okome, M. O. (2002). Domestic, Regional and International Protection of Nigerian Against Discrimination: Constraint and Possibilities. Available online at: https:// ssrn.com/abstract $=2761914$

Olomojobi, Y. (2013). Human Rights on Gender, Sex and the Law in Nigeria, Lagos: Princeton Publishing Co.

Olorunbunmi, B. (2015). "Beijing 1995: its challenges to women and development in Africa," in Women in Development Essays in Honour of Prof. D.O Akintunde, eds S. A. Ajayi and J. K. Ayantayo (Ibadan: John Archers Publishers Ltd.), 395-407.

Oloyede, O. (2016). Monitoring Participation of Women in Politics in Nigeria. Available online at: https://unstats.un.org/unsd/gender/Finland_Oct2016/ Documents/Nigeria_paper.pdf

Omotola, J. S. (2007). Gender, power and politics in the contemporary Nigeria. Af. Stud. Monogr. 28, 33-46. doi: 10.14989/68225

PLAC. (2017). Factsheets on Some 8th Assembly Bills that Impact on Women Issues. Available online at: placing.org

Sossou, M. A. (2011). We Do not Enjoy Equal Rights: Ghanaian Women's Perceptions on Political Participation in Ghana.

Uzoanya, E. P., and Awodipe, T. (2015). Nigerian women's scorecard in 2015 polls. The Guardian.

Conflict of Interest Statement: The author declares that the research was conducted in the absence of any commercial or financial relationships that could be construed as a potential conflict of interest.

Copyright $\odot 2018$ Eniola. This is an open-access article distributed under the terms of the Creative Commons Attribution License (CC BY). The use, distribution or reproduction in other forums is permitted, provided the original author(s) and the copyright owner(s) are credited and that the original publication in this journal is cited, in accordance with accepted academic practice. No use, distribution or reproduction is permitted which does not comply with these terms. 